Attadrib: Jurnal Pendidikan Guru Madrasah Ibtidaiyah

(p-ISSN: 2599-3194 | e-ISSN: 2775-8109

Volume 4, Issue. 2, 2021, pp. 89-98

\title{
Tri Pusat Pendidikan Sebagai Pembinaan Akhlak Di Sekolah Dasar Negeri
}

\author{
Nur Afni Fauziah', Yunus², \\ ${ }^{1}$ UPT SD Negeri 227 Patila, Indonesia \\ ${ }^{1}$ Universitas Pamulang, Indonesia \\ e-mail: nurafnifauziyah83@gmail.com,nurhang542@gmail.com
}

Submitted: 24-08-2021Ｒevised : 06-11-2021Ａccepted: 21-11-2021

\begin{abstract}
The study describes the concept of harmonization of three educational centers in moral development at UPT SD Negeri 230 Tondok. Tangnga, Tanalili District, North Luwu Regency. This research is a qualitative research that uses a pedagogical approach. Sources of data, namely primary data sourced from school principals, $P A I$ teachers, parents of students, the community. Meanwhile, secondary data were taken from documents related to the research. The instrument used in collecting data is the researcher himself who functions to determine and select informants as data sources, analyze data, interpret data, and the instruments in collecting data are observation, interviews, and documentation. The results showed that the role of the family as the basis of education, the school as the developer of education and the community as the user. An important role in the development and growth of students, both physically and spiritually, mentally spiritually and physically. The implementation of the barmonization of the Three Education Centers is carried out with close cooperation, it can be seen when parents lay the foundations of education, especially the family in the formation of personality. Then it is developed in a school environment with educational materials in the form of knowledge and skills. The community participates in controlling, distributing and fostering and improving it.
\end{abstract}

Keywords: Three Education Centers, Elementary Schools, Morals

ABSTRAK. Penelitian mengambarkan konsep Harmonisasi Tri Pusat Pendidikan Dalam Pembinaan Akhlak di UPT SD Negeri 230 Tondok Tangnga, Kecamatan Tanalili, Kabupaten Luwu Utara. Penelitian ini adalah penelitian kualitatif yang menggunakan pendekatan pedagogis. Sumber data yaitu data primer bersumber dari kepala sekolah, guru PAI, orang tua peserta didik, masyarakat. Sedangkan data sekunder diambil dari dokumen yang ada kaitannya dengan penelitian. Instrumen yang digunakan dalam mengumpulkan data adalah peneliti sendiri yang berfungsi menetapkan dan memilih informan sebagai sumber data, analisis data, menafsirkan data, serta instrumen dalam mengumpulkan data adalah observasi, wawancara, dan dokumentasi. Hasil penelitian menunjukkan bahwa peran keluarga sebagai dasar pendidikan, sekolah sebagai pengembang pendidikan dan masyarakat sebagai penguna. Peran penting dalam perkembangan dan pertumbuhan peserta didik, baik secara jasmani maupun rohani, mental spiritual dan fisikal. Pelaksanaan harmonisasi Tri Pusat Pendidikan dilakukan dengan kerjasama yang erat itu tampak ketika orang tua meletakkan dasar-dasar pendidikan, terutama keluarga dalam pembentukan kepribadian. Kemudian dikembangkan dalam lingkungan sekolah dengan materi pendidikan berupa ilmu dan ketrampilan. Masyarakat ikut berperan serta mengontrol, menyalurkan serta membina dan meningkatkannya.

Kata Kunci: Tri Pusat Pendidikan, Sekolah Dasar, Akhlak 


\section{doi Https://doi.org/10.54069/attadrib.v4i2.146 \\ How to Cite Fauziyah. N.A, Yunus (2021). Tri Pusat Pendidikan Sebagai Pembinaan Akhlak Di Sekolah Dasar Negeri. Attadrib: Jurnal Pendidikan Guru Madrasah Ibtidaiyah, Volume 4 (2), 89-98.}

\section{PENDAHULUAN}

Pentingnya pendidikan akhlak, karakter dan juga moral yang digunakan sebagai filterisasi agar lahir kesadaran bersama untuk membangun karakter, akhlak dan moral generasi muda bangsa yang kokoh. Sehingga mereka tidak terobang ambing oleh modernisasi yang menjanjikan kenikmatan sesaat serta mengorbankan kenikmatan masa depan yang panjang dan abadi. Termasuk dalam hal mendidik Peserta didik agar menjadi anak yang saleh.

Tujuan utama pendidikan adalah untuk membentuk manusia yang good and smart(Davidson, Lickona, \& Khmelkov, 2014; Rahmat Rifai Lubis, 2020). Dalam Islam mengupayakan agar manusia memiliki karakter yang baik (good character)(Bayu \& Rahmadina, 2020; Yunus, Nurseha, 2020). Dengan bahasa sederhana adalah merubah manusia menjadi lebih baik dalam pengetahun, sikap dan keterampilan. Namun, pada prakteknya lebih ditekankan pada aspek prestasi akademik (academic achievement), sehingga mengabaikan pembentukan karakter siswa. Mengingat sifat karakter berkembang sesuai dan sejalan dengan tahapan perkembangan anak serta lingkungan yang mempengaruhinya, pembinaan karakter seharusnya dimulai sejak usia dini, mulai saat ini juga dan setiap saat hingga hari-hari anak penuh dengan nilai-nilai karakter. Ungkapan bahwa, untuk mengajari nilai karakter terhadap anak ketika dia sudah "cukup tua untuk memilih sistem nilai mereka sendiri" merupakan ungkapan yang bisa membawa petaka buat diri anak (Hartoyo, 2011; Marzuki, 2013; Nurnaningsih, 2015).

Kurikulum yang dirancang di SD bukan saatnya lagi lebih dominan kognitif dari pada sikap dan mental, yang justru merusak moral anak bangsa. Seperti halnya peristiwa keunikan anak SD beberapa bulan silam. Masyarakat dibuat tak berkedib dengan pemberitaan 4 orang siswa SD yang membakar 21 raport dan 1 data nilai. Pasalnya, empat siswa merasa malu nilai UKK-nya dibawah standar dan sering diolok-olok temannya. Padahal sejatinya mereka ini belum tahu pasti hasil nilai UKK karena rapot kenaikan kelas juga belum dibagikan. Peristiwa nekat anak SD Sumberjo (Lamongan) ini menjadi perhatian masyarakat.

Data tersebut bukan alasan saling lempar tangan tanggung jawab, yang penting pemerintah dan pemangku kepentingan terus berupaya untuk mencari inovasi dan fomulaformula baru dalam pembentukan karakter peserta didik utamanya sekolah dasar (SD), yang notabennya sebagai generasi penerus perjuangan bangsa. Menjadi penting juga mengawal penguatan kurikulum dengan basis karakter, sehingga wacana tentang pengintegrasian mata pelajaran dengan nilai karakter bisa terwujud dan diwujudkan dalam praktek kehidupan seharihari seutuhnya.

Upaya mengaktualisasikan Islam dalam keseharian, menjadikan pendidikan Islam sebagai suatu tuntutan dan kebutuhan mutlak umat manusia untuk: 1) Menyelamatkan anak-anak dari ancaman dan hilang sebagai korban hawa nafsu para orang tua terhadap kebendaan, sistem materialistis non humanistis, pemberian kebebasan yang berlebihan dan pemanjaan. 2) Menyelamatkan anak-anak di lingkungan bangsa-bangsa yang sedang berkembang dan lemah dari ketundukan, kepatuhan, dan penyerahan diri kepada kekuasaan kezhaliman dan penjajahan.

Berdasarkan hasil observasi penulis, permasalahan yang sering dialami oleh seorang guru dalam menanamkan pendidikan dengan pembinaan karakter di sekolah, khususnya guru mata pelajaran pendidikan agama Islam di UPT SD Negeri 230 Tondok Tangnga, Kecamatan Tanalili, Kabupaten Luwu Utara, seperti ketidakjujuran peserta didik (menyontek, berbohong, berkata tidak sesuai dengan yang sesungguhnya, tidak berani mengakui kesalahan yang diperbuatnya. Guru berupaya keras dalam mengubah tutur dan perilaku peserta didik yang dimilikinya, penanaman nilai-nilai keagamaan melalui mata pelajaran agama dirasakan kurang mencukupi kebutuhan peserta didik sehingga perlu adanya penanaman nilai keagamaan. Salah satu program 
yang gencar dilakukan UPT SD Negeri 230 Tondok Tangnga, Kecamatan Tanalili, Kabupaten Luwu Utara, yakni setiap pendidik dan peserta didik wajib melakukan tadarrus al-Qur'an pada setiap jam pertama dan jam terakhir mata pelajaran selama \pm 10 menit.

Proses pembelajaran setiap pendidik harus dapat memahami hakikat anak didiknya sebagai objek pendidikan. Keberadaan anak didik dalam aktivitas pendidikan merupakan hal yang sangat vital, karena pada dasarnya pendidikan itu sendiri adalah untuk anak didik(Fadlilah, 2020; Helaluddin \& Syawal, 2018; Mumpuniarti, 2012). Maka dari itu, tujuan penelitian ini untuk melihat peran tripusat dalam pendidikan akhlak.

\section{METODE PENELITIAN}

Penelitian yang menggunakan penelitian kualitatif dengan pendekatan pedagogis. Salah satu alasan pemilihan lokasi ini adalah sekolah belum pernah dijadikan tempat penelitian sehingga sedikit ada kemudahan mencari data dan informasi dalam penelitian serta keramahan dari para guru menerima peneliti. Untuk memenuhi keabsahan data langkah yang dilakukan peneliti sebagai berikut 1) Perpanjangan keikutsertaan, 2) Ketekunan pengamatan, 3) Triangulasi.

\section{HASIL DAN PEMBAHASAN}

\section{Hasil}

Secara administrasi UPT SD Negeri 230 Tondok Tangnga beralamat di Jalan Poros Sidobinangun/Rampoang, Desa Rampoang, Kecamatan Tanalili, Kabupaten Luwu Utara. UPT SD Negeri 230 Tondok Tangnga memiliki luas lahan $4.594 \mathrm{M}^{2}$.

Usaha dalam merealisasikan karakter mulia sangat memerlukan pembangunan budaya atau kultur yang dapat mempercepat terwujudnya karakter yang diharapkan. Kultur merupakan kebiasaan atau tradisi yang sarat dengan nilai-nilai tertentu yang tumbuh berkembang dalam kehidupan sehari-hari dalam berbagai aspek kehidupan. Kultur dapat dikembangkan oleh siapapun dan di mana pun. Maka dalam usaha pembelajaran karakter mulia memerlukan peran aktif dari tiga lingkungan pendidikan yang disebut dengan tri pusat pendidikan.

\section{Keluarga}

Keluarga berpengaruh terhadap Pembinaan Akhlak religius peserta didik. Seperti penelitian yang dilakukan keluarga berpengaruh dan memiliki peran yang sangat penting bagi perkembangan seorang anak utamanya perkembangan moral. Fungsi pertama orang tua dalam kontek pengembangan karakter anak adalah sebagai model peranan. Orang tua memainkan peran penting dalam penanaman berbagai macam nilai kehidupan yang dapat diterima dan dipeluk oleh anak. Anak lebih banyak meniru dan meneladan orang tua, entah itu dari cara berbicara, berpakaian cara bertindak dan lain-lain. Peran keluarga sebagai pranata kependidikan, sebagai berikut:

Perilaku kedua orang tuanya, akhlaknya dan keyakinannya, mempunyai pengaruh yang kuat dalam pembentukan sikap dan perilaku anak-anaknya. Yang jelas bahwa anak yang hidup dalam lingkungan orang tua yang kasar, pemarah, dan jauh dari sikap dan perilaku religius (agamis), perkembanganya akan sangat berbeda dibanding dengan anak-anak yang hidup di tengah-tengah keluarga yang lemah lembut, ramah, dan berbudi luhur. Anak yang tumbuh di tengah-tengah orang tua yang tekun melakukan ibadah, mematuhi ajaran agamanya dengan baik akan berbeda dengan anak-anak yang tumbuh di tengah-tengah keluarga yang atheis (ingkar Tuhan), amoral, dan tidak mengenal ajaran agama (Titik Suyanti, 2021).

Keluarga pada hakikatnya merupakan wadah Pembinaan Akhlak masing-masing anggotanya, terutama anak-anak yang masih berada dalam bimbingan dan tanggung jawab orang tuanya. Bagaimana sebuah keluarga memperlakukan anak-anaknya akan berdampak pada perkembangan perilaku anak-anaknya. Hal tersebut sejalan dengan pernyataan Lickona yang menegaskan bahwa keluarga adalah sekolah pertama dalam membentuk karakter anak, "The 
Family is the first school of firtue, it"s where we learn about commitment, scarfice, and faith in something larger than our seleves The family lays down the moral foundation of which all other social instution build"(Davidson et al., 2014; Tom Lickona, Eric Schaps, 2002) dari pernyataan tersebut, dijelaskan bahwa keluarga adalah sekolah pertama kebajikan, dalam keluarga kita belajar tentang cinta, komitmen, pengorbanan, dan meyakini sesuatu yang lebih besar daripada diri kita sendiri, keluarga adalah peletak dasar pendidikan moral.

Mewujudkan anak yang baik dan berkualitas adalah tanggung jawab yang harus dipikul oleh orang tuanya. Anak merupakan amanah yang diberikan oleh Allah kepada orang tuanya yang harus dipertanggung jawabkannya nanti di akhirat. Karena itu wajib memelihara, membesarkan, merawat, menyantuni dan mendidik anak-anaknya dengan penuh yang tanggung jawab dan kasih sayang Ismail Suwardi Wekke, Arhanuddin Salim, 2018; Yunus, 2020). Tanggung jawab orang tua terhadap anak-anaknya bukan merupakan tanggung jawab yang ringan tetapi cukup berat. Orang tua harus menjaga anak dan seluruh anggota keluarganya selamat dari siksa api neraka sebagaimana firman Allah Swt dalam QS Al-Tahrim [66]: 6

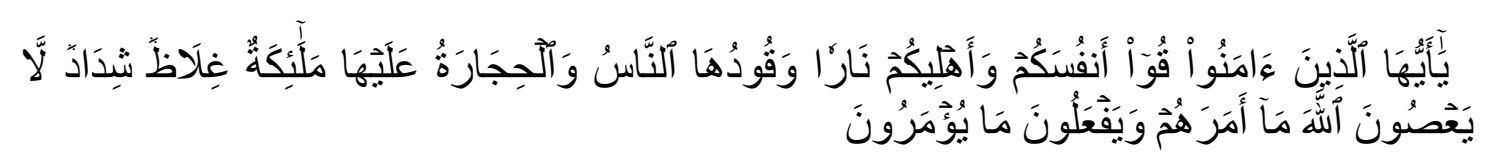

Terjemahnya:

"Hai orang-orang yang beriman, peliharalah dirimu dan keluargamu dari api neraka yang bahan bakarnya adalah manusia dan batu; penjaganya malaikat-malaikat yang kasar, keras, dan tidak mendurbakai Allab terhadap apa yang diperintabkan-Nya kepada mereka dan selalu mengerjakan apa yang diperintabkan".

Ayat di atas menggambarkan bahwa dakwah dan pendidikan harus bermula di rumah. Ayat di atas walau secara redaksional tertuju kepada kaum pria (ayah), tetapi itu bukan berarti hanya tertuju kepada mereka. Ayat ini tertuju untuk kepada lelaki dan perempuan (ibu), ini berarti kedua orang tua bertanggung jawab untuk menjaga keluarganya dari api neraka dan bertanggung jawab atas anak-anaknya dan juga pasangan masing-masing sebagaimana masing-masing bertanggung jawab atas kelakuannya. Al-Marahgi mengemukakan bahwa yang dapat menjaga dan menjauhkan kita dari api neraka adalah dengan ketaatan kepada Allah dan mematuhi perintahnya. Memelihara dan menyelamatkan keluarga dari siksaan neraka dapat dilakukan dengan cara menasehati, mengajar dan mendidik mereka.

Oleh karena itu keluarga merupakan lingkungan tempat meletakkan dasar-dasar pengalaman anak. Unsur utama yang dijadikan landasan pokok dalam pendidikan di lingkungan keluarga adalah adanya rasa kasih sayang dan terselenggaranya kehidupan beragama yang mewarnai kehidupan pribadi/keluarga. Hal tersebut bahwa dasar kepribadian seseorang terbentuk sebagai hasil perpaduan antara warisan sifat-sifat, bakat-bakat orang tua dan lingkungan di mana ia berada dan berkembang. Sikap, pandangan dan pendapat orang tua/ anggota keluarga lainnya dijadikan model oleh si anak dan ini kemudian menjadi sebagian dari tingkah laku anak itu sendiri.

Dalam penelitian ini lingkungan keluarga berpengaruh positif terhadap pembinaan akhlak peserta didik di UPT SD Negeri 230 Tondok Tangnga, Kecamatan Tanalili, Kabupaten Luwu Utara namun tidak signifikan disebabkan beberapa alasan, dari hasil wawancara bersama kepala sekolah ibu Sumarti mengatakan bahwa anak-anak yang bersekolah di sini mayoritas mempunyai orang tua yang bekerja. Di sekolah ini juga menerapkan sistem pembelajaran daring selama covid19 jadi waktu peserta didik lebih banyak dihabiskan di lingkungan keluarga, hal ini menyebabkan lingkungan keluarga berpengaruh positif. Lingkungan keluarga dapat berpengaruh signifikan jika melalui lingkungan sekolah, variabel lingkungan sekolah sebagai mediasi dari lingkungan keluarga dalam hal pembinaan akhlak. Hal ini sesuai dengan pandangan Thomas Lickona berpendangan 
bahwa sekolah dan keluarga yang bekerjasama merupakan sekutu (partner) yang kuat bagi karakter (dalam membangun karakter).

Memang pengaruh lingkungan keluarga terhadap perkembangan anak sangat mendalam dan menentukan perkembangan kepribadian anak selanjutnya, terutama ketika ia memasuki masa remaja. Hal ini disebabkan karena: 1) Pengaruh itu merupakan pengalaman yang pertama-tama, 2) Pengaruh yang diterima anak itu masih terbatas jumlah dan luasnya. 3) Intensitas pengaruh itu tinggi karena berlangsung terus menerus siang dan malam. 4) Umumnya pengaruh itu diterima dalam suasana aman dan bersifat intim dan bernada emosional.

Oleh karena itu peran dan fungsi orang tua sangat menentukan terhadap perilaku anak pada saat ini. Kita tidak bisa menyalahkan modernisasi yang sedang berjalan, tapi kita sebagai orang tua perlu kebijakan dalam menyikapi modernisasi tersebut. Pada era modernisasi seperti ini keluarga terutama orang tua harus bisa membagi peran dan waktu untuk anak-anaknya. Untuk menekan pergaulan bebas pada anak tidak cukup hanya berupa penanaman nilai keagamaan yang kuat. Akan tetapi dibutuhkan pendampingan orang tua dalam segala hal, dengan tidak mengurangi kebebasan dari seorang anak. Fungsi sosialisasi dan afeksi dalam keluarga perlu ditumbuhkan kembali, mengingat keluarga adalah salah satu Lembaga sosial yang paling dasar yang berperan membentuk karakter anak.

\section{Sekolah Terhadap Pembinaan Akhlak}

Lembaga sekolah mempengaruhi pembinaan akhlak peserta didik di UPT SD Negeri 230 Tondok Tangnga, Kecamatan Tanalili, Kabupaten Luwu Utara, hal tersebut sejalan dengan teori William Bannet menyatakan bahwa sekolah memiliki peran yang sangat urgen dalam pendidikan akhlak seorang peserta didik. Apalagi bagi peserta didik yang tidak mendapatkan pendidikan akhlak sama sekali di lingkungan dan di keluarga mereka, dalam penelitian Wiliam Bannet tentang kecenderungan masyarakat di Amerika, yang mana anak-anak menghabiskan waktu lebih lama di sekolah ketimbang di rumah mereka, dan apa yang terekam dalam memori anak didik di sekolah, ternyata mempunyai pengaruh besar bagi kepribadian atau karakter mereka ketika dewasa kelak.

Lingkungan sekolah merupakan kesatuan ruang dalam Lembaga pendidikan formal yang secara sistematis melaksanakan program bimbingan, pengajaran, atau pelatihan dalam rangka membantu para peserta didik agar mampu mengembangkan potensinya secara optimal, baik yang menyangkut aspek moral-spiritual, intelektual, emosional, sosial, maupun fisik motoriknya. Dalam lingkungan sekolah, siswa merupakan subjek dan objek yang memerlukan bimbingan dari orang lain untuk mengarahkan potensi yang dimilikinya serta bimbingannya menuju kedewasaan yang berkarakter. Dengan pembinaan akhlak secara terus menerus diharapkan dapat membentuk peserta didik yang berakhlakul karimah. Peserta didik yang mempunyai karakter yang baik akan mampu mewujudkan norma-norma dan nilai positif yang akan mempengaruhi keberhasilannya dalam pendidikan.

Dalam pembinaan sikap dan jiwa keagamaan pada anak tidak hanya terpaku pada guru. Dalam lingkungan sekolah pendidikan seorang anak dipengaruhi oleh guru dan juga temannya. Kaitannya dengan aspek pendidikan bahwa seorang pendidik hendaknya: Menuntun anak didiknya. Dalam hal ini menerapkan bahwa peran seorang guru adalah sebagai fasilitator, tutor, pendamping dan lainnya. Peran tersebut dilakukan agar anak didiknya sesuai dengan yang diharapkan bangsa dan agamnya. Memberi tahu kesulitan yang akan dihadapi dalam menuntut ilmu. Hal ini perlu karena zaman akan selalu berubah seiring berjalannya waktu. Dan kalau tidak mengikutinya maka akan menjadikan anak tertinggal. Mengarahkannya utuk mengembangkan potensi yang dimilikinya.

Selain faktor tersebut di atas, ada faktor-faktor lain seperti metode mengajar guru, kurikulum yang digunakan, relasi guru dengan peserta didik, relasi peserta didik dengan peserta didik, disiplin sekolah, keadaan gedung turut mempengaruhi aspek afektif, kognitif maupun psikomotorik. Pendidikan yang diberikan di sekolah juga merupakan dasar pada pembinaan sikap dan jiwa keagamaan pada peserta didik. Apabila guru di sekolah mampu membina sikap positif terhadap agama dan berhasil membentuk pribadi dan akhlak peserta didik. Maka ketika memasuki 
usia dewasa keberagamaan seseorang itu akan benar-benar matang. Sikap positif yang dibangun biasa berupa ketaatan pada agama, pola hubungan pertemanan, termasuk saling menghargai teman. Sebaliknya apabila guru gagal melakukan pembinaan sikap dan jiwa agama pada anak maka akan berpengaruh pula terhadap masa dewasanya. Dalam hal ini lembaga sekolah menjadi sangat penting.

Sekolah berfungsi membantu keluarga menanamkan nilai-nilai pendidikan kepada anakanak yang berhubungan dengan sikap dan kepribadian mulia serta pikiran yang cerdas sehingga nantinya akan menjadi anggota masyarakat yang bermanfaat sesuai dengan tuntutan dan tata laku masyarakat yang berlaku seiring dengan tujuan pendidikan seumur hidup.

\section{Lingkungan Masyarakat Terhadap Pembinaan Akhlak}

Lingkungan masyarakat di UPT SD Negeri 230 Tondok Tangnga, Kecamatan Tanalili, Kabupaten Luwu Utara mempengaruhi akhlak peserta didik. Hal tersebut sejalan dengan pendapat. Quraish Shihab bahwa dari perspektif Islam situasi kemasyarakatan dengan sistem nilai yang dianutnya, mempengaruhi sikap dan cara pandang masyarakat secara keseluruhan. Jika sistem nilai dan pandangan mereka terbatas pada "kini dan di sini", maka upaya dan ambisinya terbatas pada kini dan di sini pula.

Norma-norma yang ada dalam masyarakat harus diikuti oleh warganya dan norma-norma tersebut mempengaruhi kepribadian warganya dalam bertindak. Norma-norma ini adalah aturan yang diteruskan oleh generasi berikutnya. Infeksi ini dilakukan secara sadar dan dengan tujuan agar proses peran masyarakat dalam pendidikan. Masyarakat adalah lingkungan pendidikan ketiga. Pengasuhan tumbuh kembang anak harus dilakukan secara teratur dan terus menerus. Oleh karena itu, lingkungan masyarakat akan berdampak pada pertumbuhan tersebut. Jika pertumbuhan fisik akan berhenti ketika anak sudah dewasa, pertumbuhan fisik akan siap. Dalam lingkup yang lebih luas dapat diartikan bahwa nilai-nilai kesantunan atau nilai-nilai yang berkaitan dengan aspek spiritual akan lebih efektif jika seseorang berada dalam lingkungan yang menjunjung tinggi nilai-nilai tersebut.

Tri pusat pendidikan yaitu pendidikan dalam lingkungan keluarga, lingkungan sekolah dan lingkungan masyarakat merupakan sarana yang tepat dalam menanamkan dan membentuk akhlak peserta didik sekolah dasar. Hal ini sejalan dengan dengan pendapat Abdurrahman An-Nahlawi bahwa "Lingkungan pendidikan yang dapat memberi kontribusi bagi perkembangan anak ada tiga. Pertama, lingkungan keluarga sebagai penangnggung jawab utama terpeliharanya fitrah anak. Kedua, lingkungan sekolah untuk mengembangkan segala bakat atau potensi manusia sesuai fitrahnya sehingga manusia terhindar dari penyimpangan-penyimpangan. Ketiga, lingkungan masyarakat sebagai wahana interaksi sosial bagi terbentuknya nilai-nilai keagamaan dan kemasyarakatan"

Pemahaman peran keluarga, sekolah dan masyarakat sebagai lingkungan pendidikan sangat penting dalam upaya membantu perkembangan kepribadian anak secara optimal. Bukan hanya peranannya masing-masing, tetapi juga keterkaitan dan saling berpengaruh antar ketiganya dalam perkembangan manusia. Sebab pada hakikatnya ketiga pusat pendidikan itu selalu secara bersama-sama mempengaruhi manusia. Namun tidak bisa dipungkiri bahwa keluarga/orang tua yang berpengaruhi dalam pembinaan akhlak, hal diungkapkan Edhy Rustan (2020), dalam jurnal The Role Of Mubaligh And Parents In Growing Children's Character In Kampong Gayau Sarawak Malaysia, beliau mengatakan orang tua berperan dalam penumbuhan karakter anak melalui penerapan pembelajaran agama berwawasan kemasyarakatan. Religius dan toleransi merupakan karakter yang paling dominan tumbuh pada anak.

Ketiga jenis lingkungan pendidikan tersebut sangat penting, karena ketiganya merupakan komponen yang saling mengisi dan memperkuat dalam proses pendidikan anak. Sebagai contoh pengetahuan agama, sikap dan nilai yang agamis serta keterampilan beragama yang dilakukan bagi kehidupan sehari-hari biasanya dipelajari peserta didik di dalam lingkungan keluarga, sekolah dan masyarakat antara lain dengan jalan mengamati dan menirunya. Pengetahuan, sikap, nilai dan keterampilan agama maupun keterampilan umum yang ditiru seseorang dari keluarga, baru bisa 
berkembang apabila seseorang itu belajar di sekolah atau di masyarakat. Yang dimaksud dengan berkembang di sini ialah perubahan ke arah yang lebih baik. Hal ini sejalan dengan Munir Yusuf (2018) menyatakan bahwa perkembangan kepribadian serta kemampuan seseorang terjadi: 1) Atas pengaruh hal-hal yang tidak sengaja, berlangsung secara tidak terencana atau selektif bersifat insedental yang diperolehnya melalui pendidikan dalam lingkungan keluarga. 2)Atas pengaruh halhal yang sengaja, berlangsung secara sadar terencana baik yang diperolehnya melalui pendidikan lingkungan sekolah, maupun masyarakat. Masing-masing jenis lingkungan pendidikan tersebut berarti bermakna bagi perkembangan seseorang sebagai individu dan sebagai anggota masyarakat.

Maka, dapat ditarik kesimpulan betapa pentingnya tripusat pendidikan dalam mempengaruhi akhlak peserta didik. Lingkungan pendidikan tersebut saling berkaitan satu dengan yang lain begitu juga yang terjadi di UPT SD Negeri 230 Tondok Tangnga, Kecamatan Tanalili, Kabupaten Luwu Utara, lingkungan pendidikan mempengaruhi pembinaan akhlak peserta didiknya. Semakin baik kondisi lingkungan sekolah, lingkungan keluarga, dan lingkungan masyarakat peserta didik akan berpengaruh terhadap pembinaan akhlak peserta didik yang baik pula. Sebaliknya semakin buruk kondisi lingkungan sekolah, lingkungan keluarga, dan lingkungan masyarakat peserta didik akan berpengaruh buruk pula terhadap pembinaan akhlak religius peserta didik. Saptono juga menyatakan bahwa pendidikan karakter yang berhasil merupakan buah dari kerjasama yang baik antara pihak keluarga, sekolah dan masyarakat. Karakter yang baik, yan telah diajarkan kepada anak di rumah dan di sekolah membutuhkan peneguhan dalam masyarakat. Sebabnya sekolah karakter yang efektif ialah mereka yang tidak hanya bekerja sendirian (eksklusif), melainkan mereka yang bersedia bekerja secara optimal dengan orang tua siswa dan berbagai komunitas karakter.

Berdasarkan pendapat beberapa tokoh di atas, dapat disimpulkan bahwa perkembangan anak khususnya perilaku atau karakter agama tidak semata-mata dipengaruhi atau ditentukan oleh sekolah, tetapi ketiga lingkungan pendidikan tersebut sama-sama memiliki peran dan pengaruh terhadap tumbuh kembang anak. pengembangan. perkembangan, terutama perilaku atau karakter mereka. Maka di sinilah perlu terjalin kerjasama antara ketiga lingkungan pendidikan atau yang disebut dengan tripusat pendidikan menuju pengembangan akhlak bagi peserta didik

\section{Pembahasan}

Pendidikan anak-anak usia dini sangatlah penting mengingat mereka itu jiwanya masih bersih (belum banyak terkontaminasi oleh pengaruh negatif dari lingkungannya), namun mereka sangat peka terhadap pengaruh yang sampai pada mereka. Anak-anak itu merupakan amanat Allah yang dipercayakan kepada kedua orang tuanya dan para pengasuh dan pendidiknya. "jiwanya yang suci merupakan permata yang sangat berharga yang bersih dari noda dan cacat". Pandangan Al-Ghazali tersebut tidak terlepas dari prinsip "al-Fitrab" dalam pengertian jiwa anakanak itu masih bersih dari pengaruh dan pengalaman serta pengetahuan, meskipun jiwa tersebut memiliki naluri dan kecenderungan serta potensi yang dapat dipengaruhi dan dikembangkan terutama oleh lingkungan sosial yang dominan di sekitarnya. Di sini Al-Ghazali sangat serius memandang pentingnya "lingkungan pendidikan", apakah itu pendidikan keluarga, atau pendidikan persekolahan, atau pendidikan masyarakat.

Maka dapat disimpulkan bahwa lingkungan pendidikan mempunyai pengaruh besar terhadap perkembangan dan pembinaan akhlak peserta didik, hal tersebut juga terjadi di UPT SD Negeri 230 Tondok Tangnga, Kecamatan Tanalili, Kabupaten Luwu Utara di mana ketiga lingkungan tersebut berpengaruh terhadap pembinaan akhlak peserta didik. Faktor yang mempengaruhi pembinaan akhlak seseorang adalah pengaruh genetika atau pembawaan dan pengaruh lingkungan (lingkungan keluarga, lingkungan sekolah dan lingkungan masyarakat). 
Tabel. 1. Faktor yang mempengaruhi akhlak

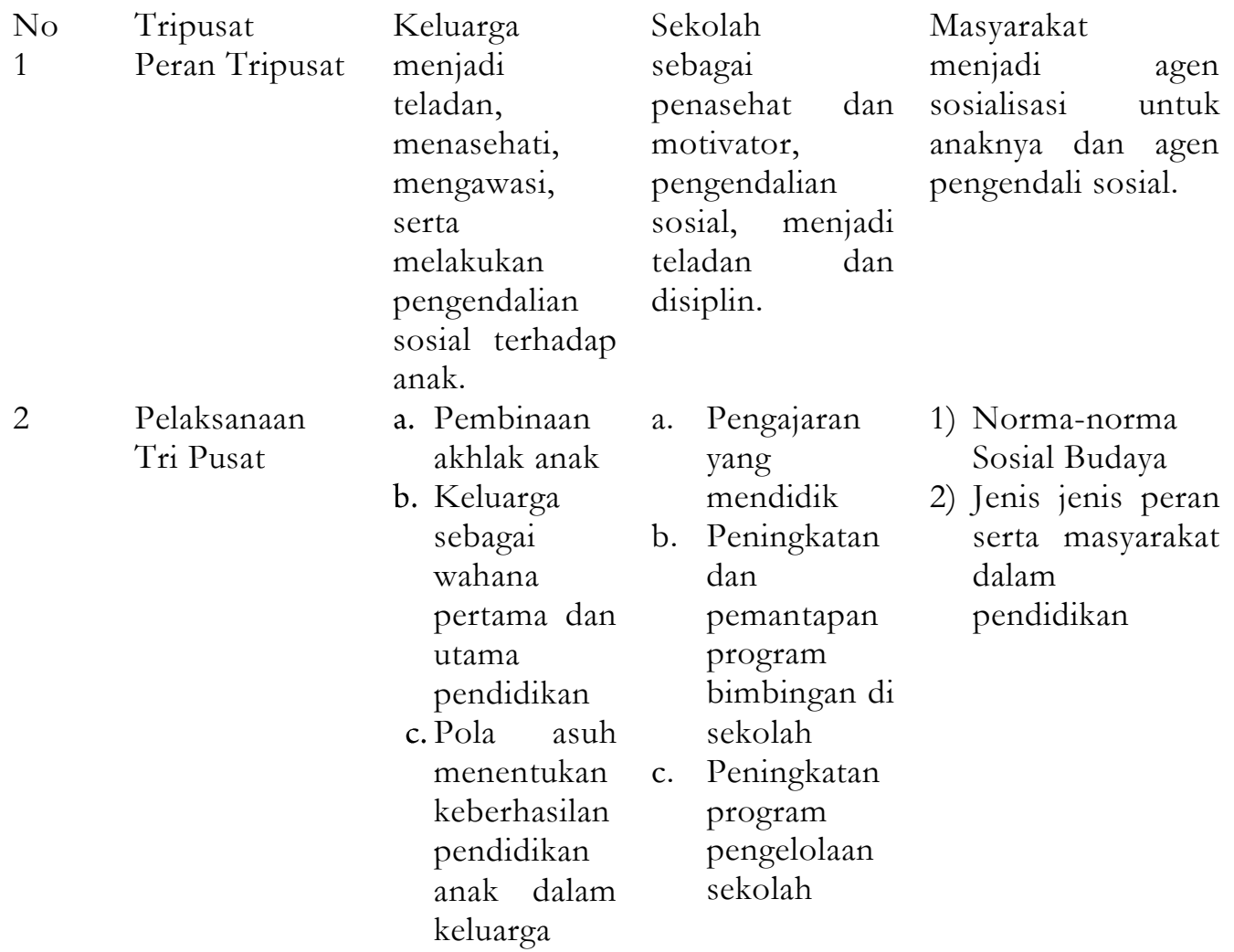

Pola Pengaruh Lingkungan keluarga yang merupakan lingkungan Tripusat pertama dan dianggap sebagi peletak dasar pendidikan Pendidikan anak yang sekaligus awal dari pendidikan yang akan ditempuh selanjutnya juga sangat berperan dalam pembentukan kepribadian. Lingkungan sekolah adalah lingkungan kedua yang dihadapi oleh peserta didik. Pendidikan dalam lingkungan sekolah mempunyai dasar tujuan, isi, metode dan syarat-syarat lain yang disusun secara sistematis dalam bentuk kurikulum. Oleh karen itu, sekolah dianggap sebagai peletak dasar pengetahuan ilmiah. Sementara itu, Lingkungan masyarakat mempunyai pengaruh yang sangat besar terhadap perkembangan anak selanjutnya. Dalam masyarakatlah anak akan merealisasikan sejumlah teori pendidikan dan pengajaran yang pernah diajarkan dalam Lembaga pendidikan sebelumnya. Sebab bagaimanapun juga, anak akan mengaktualisasikan dan melibatkan diri dalam lingkungan masyarakat.

Berdasarkan wawancara dan teori, penulis menarik kesimpulan lingkungan keluarga hendaknya lebih memperhatikan lagi perkembangan peserta didik dalam segala aspek, karena lingkungan keluarga merupakan lingkungan yang utama dan terdekat dari peserta didik, orang tua harus lebih memperhatikan lagi pola asuh terhadap peserta didik, relasi antara keluarga dan segala hal yang dapat membantu peserta didik dalam kehidupannya. Namun masyarakat dalam kiprahnya sangat mempengaruhi pendidikan baik tujuan pendidikan maupun prakteknya. Apa yang diajarkan dan dibudayakan tentang nilai-nilai dalam pendidikan tidak boleh bertentangan dengan nilai-nilai yang berkembang dalam suatu masyarakat. Apa yang dianggap luhur dalam suatu masyarakat juga akan diajarkan dan dibudayakan dalam pendidikan. Karena masyarakat 
yang peradabannya maju, pendidikannya tinggi maka akan mempengaruhi pendidikannya juga maju. Sebaliknya masyarakat yang pendidikannya rendah maka pendidikan yang berkembang di masyarakat tersebut juga kurang baik.

\section{KESIMPULAN}

Peran Tri Pusat Pendidikan Dalam Pembinaan Akhlak di UPT SD Negeri 230 Tondok Tangnga, Kecamatan Tanalili, Kabupaten Luwu Utara adalah kombinasi antara keluarga sebagai dasar pendidikan, sekolah sebagai pengembang pendidikan dan masyarakat sebagai pemakai. Kerjasama yang terpadu tersebut sangat menguntungkan dalam perkembangan dan pertumbuhan anak, baik secara jasmani maupun rohani. Lingkungan keluarga hendaknya lebih memperhatikan lagi perkembangan peserta didik dalam segala aspek, karena lingkungan keluarga merupakan lingkungan yang utama dan terdekat dari peserta didik, orang tua harus lebih memperhatikan lagi pola asuh terhadap peserta didik, relasi antara keluarga dan segala hal yang dapat membantu peserta didik dalam kehidupannya. Namun masyarakat dalam kiprahnya sangat mempengaruhi pendidikan baik tujuan pendidikan maupun prakteknya. Apa yang diajarkan dan dibudayakan tentang nilai-nilai dalam pendidikan (sekolah) tidak boleh bertentangan dengan nilai-nilai yang berkembang dalam suatu masyarakat.

\section{REFERENSI}

Bayu, Y., \& Rahmadina, A. (2020). Peran Orang Tua dalam Menanamkan Nilai Karakter Kearifan Lokal Pada Masyarakat Pesisir. Edukasi, 14(2), 145-150.

Davidson, M., Lickona, T., \& Khmelkov, V. (2014). Smart \& good schools a new paradigm for high school character education. Handbook of Moral and Character Education. https://doi.org/10.4324/9780203114896

Departemen Agama RI, al-Qur'an dan Terjemahnya, Jakarta: Yayasan Penyelenggara Penerjemah/Penafsir al-Qur'an, 2010.

Fadlilah, A. N. (2020). Strategi Menghidupkan Motivasi Belajar Anak Usia Dini Selama Pandemi COVID-19 melalui Publikasi. Jurnal Obsesi : Jurnal Pendidikan Anak Usia Dini, 5(1), 373. https://doi.org/10.31004/obsesi.v5i1.548

Hartoyo, h. A. (2011). Potensi Pembinaan Karakter Berbasis Budaya Masyarakat, 1, 19-30.

Helaluddin, \& Syawal, S. (2018). Psikoanalisis Sigmund Freud dan Implikasinya dalam Pendidikan. Research Gate, (March), 1-16.

Ismail Suwardi Wekke, Arhanuddin Salim, Y. S. (2018). Pendidikan Karakter Dalam Masyarakat Bugis. Ijtimaiyya: Jurnal Pengembangan Masyarakat Islam, 11(1), 41-62. https://doi.org/10.24042/ijpmi.v11i1.3415

Marzuki. (2013). Revitalisasi Pendidikan Agama Di Sekolah Dalam Pembangunan Karakter Bangsa Di Masa Depan. Jurnal Pendidikan Karakter, (1), 64-76. https://doi.org/10.21831/jpk.v0i1.1288

Mumpuniarti. (2012). Pembelajaran Nilai Keberagaman Dalam Pembentukan Karakter Siswa Sekolah Dasar Inklusi. Jurnal Pendidikan Karakter, (3). https://doi.org/10.21831/jpk.v0i3.1231

al-Nasir, Muhammad Zuhair Bin Nasir. (1422 H). Bab Idha Aslama al-Sabi Fama>ta Hal Yusalla 'Alaibi Wa Hal Yu'Radu 'Ala al-Sabi al-Islam, Cet. I, Juz II, nomor hadis 1358, Beirut: Dar Tauq al-Najah Musawwarah 'An al-Sultaniyah Bi Idafat Tarqim Muhammad Fuad 'Abd alBaqi.

Nurnaningsih, N. (2015). Rekonstruksi Falsafah Bugis dalam Pembinaan Karakter: Kajian Naskah Paaseng Toriolo Tellumpoccoe. Jurnal Lektur Keagamaan, 13(2), 393. https://doi.org/10.31291/jlk.v13i2.232 
Rahmat Rifai Lubis, dkk. (2020). Pembelajaran Al-Qur'an Era Covid-19: Tinjauan Metode dan Tujuannya pada Masyarakat di Kutacane Aceh Tenggara. Kutta: Jurnal Ilmu Pendidikan Islam, 4(2), 1-9. https://doi.org/10.30736/ktb.v4i2.275

Rustan, Edhy, Miftahul Jannah Akmal, (2020), The Role Of Mubaligh And Parents In Growing Children's Character In Kampong Gayau Sarawak Malaysia, Al-Balagh: Jurnal Dakwah dan Komunikasi, Vol. 5, No. 2, July - December, 193-222.

Shihab, M. Quraish. (1996). Wawasan al-Qur"an: Tafsir Maudhu'I atas Pelbagai Persoalan Umat. Bandung: Mizan, 321.

Sumarti, (2021) Kepala UPT SD Negeri 230 Tondok Tangnga, wawancara, pada tanggal 03 Februari di Sidobinangun.

Suyanti, Titik 2021) Guru Kelas I, wawancara, pada tanggal 16 Februari di Sidobinangun.

Tom Lickona, Eric Schaps, C. L. (2002). Eleven Principles of Effective Character Education.

T. E. Lickona, Schaps, and C. Lewis. (2003). CEP's Eleven Principles of Effective Character Education, Washington DC: Character Education Partnership, 56.

Yunus, Nurseha, M. (2020). Culture of Siri' in Learning Akidah Akhlak in MAN Suli Luwu District Budaya Siri' dalam. JIEBAR : Journal of Islamic Education: Basic and Applied Research, 01, 107-120.

Yunus, M. (2020). SOSIAL-BUDAYA: HARMONISASI AGAMA DAN BUDAYA DALAM PENDIDIKAN TOLERANSI. Kalam Jurnal Agama Dan Sosial Humaniora, 8(2), 1-26.

Yusuf, Munir (2018). Pengantar Ilmu Pendidikan, (Palopo: Lembaga Penerbit Kampus IAIN Palopo, 29. 